\section{Effect of Uniconazole on the Control of Plant Height and Fruit Yield of Potted Tomato, Pepper, and Eggplant}

\author{
Lucia E. Villavicencio $^{1,3}$, James A. Bethke ${ }^{2,4}$, and Lea Corkidi
}

AdDitionAl INDEX wORDs. Capsicum annuum, Solanum lycopersicum, Solanum melongena, plant growth regulators

Summary. Two experiments were conducted to evaluate the effect of the plant regulator uniconazole on plant height, flowering, and fruit yield of vegetable transplants. In the first experiment, seedlings of tomato (Solanum lycopersicum 'Early Girl'), pepper (Capsicum annuum 'Jalapeno'), and eggplant (Solanum melongena 'Millionaire'), were sprayed with water (untreated control) or with 2.5, 5 , and $10 \mathrm{mg} \cdot \mathrm{L}^{-1}$ of uniconazole. Five weeks after treatment (WAT), application of $2.5 \mathrm{mg} \cdot \mathrm{L}^{-1}$ of uniconazole reduced the height of tomato by $17 \%$, and of 5 and 10 $\mathrm{mg} \cdot \mathrm{L}^{-1}$, by $25 \%$. The effect of $10 \mathrm{mg} \cdot \mathrm{L}^{-1}$ of uniconazole on tomato plant height persisted until 13 WAT, but did not affect fruit yield. 'Early Girl' tomato plants treated with $10 \mathrm{mg} \cdot \mathrm{L}^{-1}$ of uniconazole were still shorter than the untreated control at this time, but there were no significant differences in the number or weight of the fruit produced by the plants treated with $10 \mathrm{mg} \cdot \mathrm{L}^{-1}$ of uniconazole, and the untreated controls. In contrast, as the rate of uniconazole increased, the height of 'Jalapeno' pepper and 'Millionaire' eggplant decreased. Application of uniconazole had no effect on the number of fruit produced by 'Millionaire' eggplant. However, treatment with $10 \mathrm{mg} \cdot \mathrm{L}^{-1}$ of uniconazole reduced the number of fruit produced by pepper plants by $\mathbf{5 0 \%}$, and reduced the total weight of fruit produced by pepper and eggplant plants by $30 \%$ and $50 \%$, respectively, compared with the untreated control. The second experiment analyzed the effects of 5,8 , and $10 \mathrm{mg} \cdot \mathrm{L}^{-1}$ of uniconazole on two cultivars of tomato with different growth habit, Early Girl (determinate) and Sun Sugar (indeterminate). Application of all rates of uniconazole decreased plant height but not the final fruit yield of the two tomato cultivars.

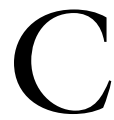
ommercial nursery crop production in the United States involves the use of chemical plant growth regulators (PGRs) to control plant growth and height (Hayashi et al., 2001; Latimer and Scoggins, 2012). Compact plants are easier to transplant, maintain, and transport, and are more attractive to consumers than tall, stretched plants with elongated internodes (Latimer and Scoggins, 2012). In addition to improved plant

We thank Altman Plants for providing plants and funding for this study, and Alexandra Treviño for technical assistance during the greenhouse experiments. Special thanks to Cheryl Wilen, Donald J. Merhaut, and César Aguilar for carefully reviewing this manuscript.

Mention of trademark, proprietary product, or vendor, does not constitute a guarantee or warranty of the product by the authors and does not imply its approval to the exclusion of other products or vendors that may also be suitable.

${ }^{1}$ Center for Applied Horticultural Research, 3742 Blue Bird Canyon Road, Vista, CA 92084

${ }^{2}$ University of California Cooperative Extension, San Diego County, 9335 Hazard Way, Suite 201, San Diego, CA 92123

${ }^{3}$ Current address: ICL 7200 Investment Drive, North Charleston, SC 29418

${ }^{4}$ Corresponding author. E-mail: jabethke@ucanr.edu. growth habit and aesthetic value, management practices using PGRs may offer other advantages for nursery production practices. It has been shown that the application of PGRs can increase seedling survival and tolerance to transplanting shock (Cha-um et al., 2009; Dunlap et al., 1991), improve resistance to environmental stress (Al-Rumaih and Al-Rumaih, 2007; Duan et al., 2008; Lurie et al., 1995), enhance flowering (Banko and Landon, 2005; Cochran and Fulcher, 2013; Keever and McGuire, 1991), and increase fruit yield (Dunlap et al., 1991; Wang and Gregg, 1990).

The objective of this study was to evaluate the effect of uniconazole on potted vegetable transplants. Vegetable gardening is gaining popularity $(\mathrm{Na}-$ tional Gardening Association, 2009), and this is the only PGR that can legally be used on some vegetable crops. Uniconazole is a triazole growth retardant that has been approved for a few species in the Solanaceae family (e.g., tomato, pepper, eggplant); however, it can only be applied as a spray, no later than $14 \mathrm{~d}$ after the four-leaf stage, and the total amount of product used cannot exceed $10 \mathrm{mg} \cdot \mathrm{L}^{-1}$ (Valent U.S.A. Corp., 2008).

Application of uniconazole has been shown to reduce stem elongation and control the height of certain vegetables (Dunlap et al., 1991; Hickman et al., 1989; Shin et al., 2009). However, there is little information on its effect on their flowering time and fruit yield. A limited number of studies have been conducted on the effect of uniconazole on tomato plants, and they have provided contrasting results. Hickman et al. (1989) found no differences in 'Royal Flush' tomato fruit yield when uniconazole was applied at concentrations from 0.25 to $5 \mathrm{mg} \cdot \mathrm{L}^{-1}$; but increased or decreased fruit yields have also been reported in different cultivars and with different rates (Dunlap et al., 1991; Wang and Gregg, 1990). Other vegetables have also shown a wide range of responses to uniconazole. Lettuce (Latuca sativa) and broccoli (Brassica oleracea var. italica) decreased yield after treatment, but watermelon (Citrullus lanatus) and pepper increased or decreased yield, depending on the cultivar (Dunlap et al., 1991). To better understand the effects of uniconazole on the growth of vegetables, more studies testing the effect of this PGR on several species and cultivars are needed. We evaluated the effect of uniconazole on height and fruit yield of 'Jalapeno' pepper, 'Millionaire' eggplant, and two tomato cultivars with different growth habits, Early Girl (determinate) and Sun Sugar (indeterminate), all popular home grown

\begin{tabular}{llll}
\hline $\begin{array}{l}\text { Units } \\
\begin{array}{l}\text { To convert U.S. to SI, } \\
\text { multiply by }\end{array}\end{array}$ & U.S. unit & SI unit & $\begin{array}{l}\text { To convert SI to U.S., } \\
\text { multiply by }\end{array}$ \\
\hline 35.3696 & $\mathrm{fl} \mathrm{oz} / \mathrm{yard}^{2}$ & $\mathrm{~mL} \cdot \mathrm{m}^{-2}$ & 0.0283 \\
3.7854 & $\mathrm{gal}$ & $\mathrm{L}$ & 0.2642 \\
2.54 & inch(es) & $\mathrm{cm}$ & 0.3937 \\
16.3871 & inch & $\mathrm{cm}^{3}$ & 0.0610 \\
28.3495 & $\mathrm{oz}$ & $\mathrm{g}$ & 0.0353 \\
1 & $\mathrm{ppm}$ & $\mathrm{mg} \cdot \mathrm{L}^{-1}$ & 1 \\
$\left({ }^{\circ} \mathrm{F}-32\right) \div 1.8$ & ${ }^{\circ} \mathrm{F}$ & ${ }^{\circ} \mathrm{C}$ & $\left({ }^{\circ} \mathrm{C} \times 1.8\right)+32$
\end{tabular}


vegetables in the United States (Gao et al., 2010; National Gardening Association, 2009).

\section{Materials and methods}

To analyze the effect of uniconazole on the height and fruit yield of vegetable transplants, two greenhouse experiments were conducted at the Center for Applied Horticultural Research (CfAHR) in Vista, CA from 25 Mar. 2010 to 31 July 2010.

\section{First experiment}

Effect of uniconazole on plant height and fruit yield of 'Early Girl' tomato, 'Jalapeno' pepper and 'Millionaire' eggplant was studied.

Pretransplanting phase. Seedlings of 'Early Girl' tomato, 'Jalapeno' pepper, and 'Millionaire' eggplant were obtained from a local source, and were planted into six-cell trays $\left(167.6 \mathrm{~cm}^{3}\right.$ per cell; East Jordan Plastics, East Jordan, MI) filled with soilless substrate (Sunshine Mix No. 2; Sun Gro Horticulture, Bellevue, WA), on 25 Mar. 2010. Plants were placed in an unheated quonset house under natural irradiance. They were fertilized with $200 \mathrm{mg} \cdot \mathrm{L}^{-1}$ nitrogen as $20 \mathrm{~N}-$ 4.3P-16.6K (20-10-20 Peters Professional Peat-Lite Special ${ }^{\circledR}$; Scotts, Marysville, $\mathrm{OH}), 2 \mathrm{~d}$ after transplanting, and with $200 \mathrm{mg} \cdot \mathrm{L}^{-1} \mathrm{~N}$ as $15 \mathrm{~N}-$ 2.15P-12.5K (15-5-15 Peters Excel ${ }^{\circledR}$ Cal-Mag, Scotts) every week, thereafter, for an additional 13 weeks for tomato plants, and 20 weeks for pepper and eggplant. Mean and standard deviation for daily temperature and relative humidity during the experimental period were $21.3 \pm 9.4^{\circ} \mathrm{C}$, and $66.5 \% \pm 28.1 \%$, respectively.

Treatments with uniconazole (Sumagic; Valent, Walnut Creek, CA) started once the seedlings reached the four-leaf stage. Plants were divided in four groups of six replicates of six-cell trays each, and the height of one plant per tray was measured before treatment application. Each group was sprayed once with water (untreated control) or with uniconazole at 2.5, 5 , or $10 \mathrm{mg} \cdot \mathrm{L}^{-1}$. All treatments were applied uniformly as a single foliar spray at a volume of $204 \mathrm{~mL} \cdot \mathrm{m}^{-2}$ using a 4-gal backpack sprayer (Solo, Newport News, VA). The experiment was arranged in a completely randomized design. The height of one randomly selected plant per tray (six per treatment) was recorded weekly during 5 weeks for tomato and 8 weeks for pepper and eggplant.

Posttransplanting phase. To determine the persistence on height control provided by uniconazole and its effect on fruit yield, one plant per tray was selected at random and transplanted into a 21 -cm-diameter $(3670$ $\mathrm{cm}^{3}$ ) plastic container (Poppelmann Plastics USA, Claremont, NC). Tomato plants were transplanted 5 WAT; eggplant and pepper at 8 WAT. Plant height and fruit yield were determined at the end of the experimental period (13 WAT for tomato plants, and 20 WAT for pepper and eggplant). Fruit yield was measured by counting and weighing all fruit present per plant.

\section{Second experiment}

Effect of uniconazole on plant height and fruit yield of tomato 'Early Girl' and 'Sun Sugar' was studied.

Pretransplanting Phase. Seeds of 'Early Girl' and 'Sun Sugar' tomato were planted in 8.45 -cm-diameter $\left(227 \mathrm{~cm}^{3}\right)$ plastic containers filled with soilless substrate (Euromix, Sun Gro Horticulture) on 29 May 2010. Once seeds germinated, plants were fertilized weekly with $200 \mathrm{mg} \cdot \mathrm{L}^{-1} \mathrm{~N}$ as $15 \mathrm{~N}-$ $2.15 \mathrm{P}-12.5 \mathrm{~K}$. They were placed on benches in a greenhouse with temperature set points of $24^{\circ} \mathrm{C}$ during the day (0800-2000 HR) and $18.3^{\circ} \mathrm{C}$ at night (2000-0800 HR). Mean and standard deviation for daily temperature and relative humidity during the experimental period were $23.5 \pm 5.7^{\circ} \mathrm{C}$, and $70.4 \% \pm 20.4 \%$, respectively.

Seedlings were divided into four groups of five plants each $(n=20)$. Plants were treated with water (untreated controls), or with uniconazole at 5,8 , or $10 \mathrm{mg} \cdot \mathrm{L}^{-1}$ at the four-leaf stage on 18 June 2010 . All treatments were applied uniformly as a single foliar spray at a volume of $204 \mathrm{~mL} \cdot \mathrm{m}^{-2}$ using a 4-gal backpack sprayer.

The experiment was arranged in a completely randomized design with five replicates per treatment. Plant height was measured before treatment application and weekly thereafter during the next 4 weeks.

Posttransplanting phase. To determine the length of height control provided by uniconazole and its effect on fruit yield, all plants were transplanted into $21-\mathrm{cm}$-diameter $\left(3670 \mathrm{~cm}^{3}\right)$ plastic containers, 4 WAT. Plant height and the number of flowers were assessed weekly for an additional 8 weeks. Fruit yield was also determined by harvesting, counting, and weighing all fruit produced per plant, 5 to 12 WAT.

\section{Data analysis}

A two-way analysis of variance (ANOVA) was used to analyze the effect of the different concentrations of uniconazole on the height of the different species over time, in the first experiment, and on the height, number of flowers and fruit, in the second. When interactions between concentration and time were significant, one-way ANOVA was used to determine significant differences among uniconazole concentration at each date. Data were analyzed using JMP (version 9.0; SAS Institute, Cary, NC). Logarithmic transformation was applied to satisfy assumptions of normality and homogeneity of variance. Means were compared using the Fisher's protected least significant difference test $(P \leq 0.05)$.

\section{Results \\ First experiment}

Effect of uniconazole on plant height and fruit yield of 'Early Girl' tomato, 'Jalapeno' pepper, and 'Millionaire' eggplant was studied.

Pretransplanting phase. The two-way ANOVA indicated significant interactions between the uniconazole treatment and time on the height of tomato, pepper, and eggplant (Table 1). Application of

Table 1. Two-way analysis of variance of effect of $0,2.5,5$, and $10 \mathrm{mg} \cdot \mathrm{L}^{-1}(\mathrm{ppm})$ of uniconazole on the height of 'Early Girl' tomato, 'Jalapeno' pepper, and 'Millionaire' eggplant during the pretransplanting phase [ 1 to 5 weeks after treatment (WAT) for tomato and 1 to 8 WAT for pepper and eggplant].

\begin{tabular}{lccc}
\hline & Uniconazole concn & Time & Uniconazole $\times$ time \\
\cline { 2 - 4 } Crop & \multicolumn{3}{c}{ F ratio } \\
\hline 'Early Girl' tomato & $163.52^{* * *}$ & $362.80^{* * *}$ & $4.54^{* * *}$ \\
'Jalapeno' pepper & $303.72^{* * *}$ & $631.60^{* * *}$ & $46.94^{* * *}$ \\
'Millionaire' eggplant & $289.65^{* * *}$ & $676.99^{* * *}$ & $28.12^{* * *}$ \\
\hline$* * *$ Significant at $P \leq 0.0001$. & &
\end{tabular}


uniconazole reduced the height of these three species compared with the untreated control, but the effect of the different concentrations of uniconazole on plant height varied with time (Table 2). One week after treatment, there were no statistically significant differences among the height of the tomato plants grown with $2.5,5$, or $10 \mathrm{mg} \cdot \mathrm{L}^{-1}$ of uniconazole. However, 2 to 4 WAT, tomato plants treated with 5 and $10 \mathrm{mg} \cdot \mathrm{L}^{-1}$ of uniconazole were shorter than those treated with $2.5 \mathrm{mg} \cdot \mathrm{L}^{-1}$ (Table 2). Compared with the untreated control, application of $2.5 \mathrm{mg} \cdot \mathrm{L}^{-1}$ of uniconazole reduced the height of tomato by $17 \%$, and of 5 and 10 $\mathrm{mg} \cdot \mathrm{L}^{-1}$ of uniconazole by $\approx 25 \%, 5$ WAT (Table 2 ).
Plants of 'Jalapeno' pepper and 'Millionaire' eggplant were more responsive to uniconazole compared with 'Early Girl' tomato. As the rate of uniconazole increased, the height of the pepper and eggplant plants decreased, earlier in the growing period (Table 2). At the end of the pretransplanting phase ( $8 \mathrm{WAT})$, application of 5 and $10 \mathrm{mg} \cdot \mathrm{L}^{-1}$ of uniconazole reduced the height of plants of pepper by up to $50 \%$ and $60 \%$, respectively; and eggplant plants treated with $10 \mathrm{mg} \cdot \mathrm{L}^{-1}$ of uniconazole were $50 \%$ shorter than the untreated control (Table 2).

Posttransplanting phase. Thirteen WAT, there were no significant differences between the height of 'Early Girl' tomato treated with 2.5 or $5 \mathrm{mg} \cdot \mathrm{L}^{-1}$ of uniconazole and the untreated control, but the effect of $10 \mathrm{mg} \cdot \mathrm{L}^{-1}$ of uniconazole on plant height persisted during the posttransplanting phase (Table 3). Tomato plants treated with this concentration were still $20 \%$ shorter than the untreated controls, 13 WAT. Five and $10 \mathrm{mg} \cdot \mathrm{L}^{-1}$ of uniconazole reduced the height of pepper by $28 \%$, and of eggplant by $\approx 27 \%$ and $47 \%$, respectively, compared with the control, 20 WAT (Table 3).

None of the concentrations of uniconazole applied to 'Early Girl' tomato, affected fruit yield. There were no significant differences in the number or weight of tomato fruit produced by the untreated controls or by the plants treated with the different concentrations of uniconazole.

Table 2. Effect of $0,2.5,5$, and $10 \mathrm{mg} \cdot \mathrm{L}^{-1}$ of uniconazole on the plant height of 'Early Girl' tomato, 'Jalapeno' pepper, and 'Millionaire' eggplant during the pretransplanting phase [ 1 to 5 weeks after treatment (WAT) for tomato and 1 to 8 WAT for pepper and eggplant]. Data represent the mean of six replicates per treatment.

\begin{tabular}{|c|c|c|c|c|c|c|c|c|c|}
\hline \multirow[b]{2}{*}{ Crop } & \multirow{2}{*}{$\begin{array}{c}\text { Uniconazole } \\
\text { concn }\left(\mathrm{mg} \cdot \mathrm{L}^{-1}\right)^{\mathrm{z}}\end{array}$} & \multicolumn{8}{|c|}{ Plant ht $[\text { mean } \pm S E(\mathrm{~cm})]^{\mathrm{z}}$} \\
\hline & & I WAT & 2 WAT & 3 WAT & 4 WAT & 5 WAT & $6 \mathrm{WAT}$ & 7 WAT & 8 WAT \\
\hline \multirow[t]{3}{*}{ 'Early Girl' tomato } & 0 & $8.0 \mathrm{a}^{\mathrm{y}}$ & $11.1 \mathrm{a}$ & $14.5 \mathrm{a}$ & $16.5 \mathrm{a}$ & $17.0 \mathrm{a}$ & & & \\
\hline & 5 & $5.9 \mathrm{~b}$ & $8.6 \mathrm{c}$ & $10.0 \mathrm{c}$ & $11.4 \mathrm{c}$ & $13.7 \mathrm{~b}$ & & & \\
\hline & 10 & $5.6 \mathrm{~b}$ & $8.0 \mathrm{c}$ & $9.1 \mathrm{c}$ & $10.8 \mathrm{c}$ & $12.7 \mathrm{c}$ & & & \\
\hline \multirow[t]{2}{*}{ 'Jalapeno' pepper } & 0 & $4.7 \mathrm{a}$ & $5.7 \mathrm{a}$ & $8.8 \mathrm{a}$ & $8.8 \mathrm{a}$ & $12.7 \mathrm{a}$ & $15.9 \mathrm{a}$ & $22.9 \mathrm{a}$ & $32.5 \mathrm{a}$ \\
\hline & 10 & $3.2 \mathrm{~b}$ & $3.6 \mathrm{c}$ & $4.2 \mathrm{c}$ & $4.8 \mathrm{c}$ & $6.0 \mathrm{~d}$ & $7.1 \mathrm{~d}$ & $8.8 \mathrm{~d}$ & $11.7 \mathrm{~d}$ \\
\hline \multirow[t]{4}{*}{ 'Millionaire' eggplant } & 0 & $4.1 \mathrm{a}$ & $6.8 \mathrm{a}$ & $8.7 \mathrm{a}$ & $10.5 \mathrm{a}$ & $13.3 \mathrm{a}$ & $14.3 \mathrm{a}$ & $18.3 \mathrm{a}$ & $22.4 \mathrm{a}$ \\
\hline & 2.5 & $3.4 \mathrm{~b}$ & $5.3 \mathrm{~b}$ & $7.4 \mathrm{~b}$ & $8.5 \mathrm{~b}$ & $11.3 \mathrm{~b}$ & $13.9 \mathrm{a}$ & $18.4 \mathrm{a}$ & $21.0 \mathrm{ab}$ \\
\hline & 5 & $3.1 \mathrm{bc}$ & $4.5 \mathrm{c}$ & $6.0 \mathrm{c}$ & $6.9 \mathrm{c}$ & $9.2 \mathrm{c}$ & $11.3 \mathrm{~b}$ & $15.7 \mathrm{~b}$ & $20.4 \mathrm{~b}$ \\
\hline & 10 & $2.8 \mathrm{c}$ & $3.8 \mathrm{~d}$ & $4.9 \mathrm{~d}$ & $5.0 \mathrm{~d}$ & $5.4 \mathrm{~d}$ & $6.1 \mathrm{c}$ & $7.6 \mathrm{c}$ & $9.5 \mathrm{c}$ \\
\hline
\end{tabular}

${ }^{\mathrm{z}} 1 \mathrm{mg} \cdot \mathrm{L}^{-1}=1 \mathrm{ppm} ; \mathrm{l} \mathrm{cm}=0.3937$ inch

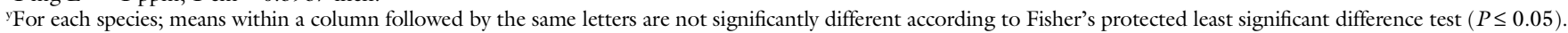

Table 3. Effect of $0,2.5,5$, and $10 \mathrm{mg} \cdot \mathrm{L}^{-1}$ of uniconazole on the plant height and fruit yield of 'Early Girl' tomato, 'Jalapeno' pepper, and 'Millionaire' at the end of the posttransplanting phase [ 13 weeks after treatment (WAT) for tomato, and 20 WAT for pepper and eggplant]. Data represent the mean of six replicates per treatment.

\begin{tabular}{|c|c|c|c|c|}
\hline \multirow[b]{2}{*}{ Crop } & \multirow{2}{*}{$\begin{array}{c}\text { Uniconazole } \\
\text { concn }\left(\mathbf{m g} \cdot \mathrm{L}^{-1}\right)^{\mathrm{z}}\end{array}$} & Plant ht $(\mathrm{cm})^{\mathrm{z}}$ & Fruit (no./plant) & Fruit wt (g/plant $)^{2}$ \\
\hline & & \multicolumn{3}{|c|}{ mean $\pm \mathrm{SE}$} \\
\hline \multirow[t]{3}{*}{ 'Early Girl 'tomato } & 0 & $51.7 \mathrm{a}^{\mathrm{y}}$ & $5.3 \mathrm{a}$ & $188.8 \mathrm{a}$ \\
\hline & 5 & $49.5 \mathrm{a}$ & $5.0 \mathrm{a}$ & $223.3 \mathrm{a}$ \\
\hline & 10 & $41.5 \mathrm{~b}$ & $5.3 \mathrm{a}$ & $205.8 \mathrm{a}$ \\
\hline \multirow[t]{2}{*}{ 'Jalapeno' pepper } & 0 & $56.4 \mathrm{a}$ & $19.5 \mathrm{a}$ & $222.3 \mathrm{a}$ \\
\hline & 10 & $41.4 \mathrm{~b}$ & $9.8 \mathrm{~b}$ & $150.8 \mathrm{~b}$ \\
\hline \multirow[t]{4}{*}{ 'Millionaire' eggplant } & 0 & 39.9 a & $7.8 \mathrm{a}$ & $452.0 \mathrm{a}$ \\
\hline & 2.5 & $34.2 \mathrm{ab}$ & $8.2 \mathrm{a}$ & $371.0 \mathrm{a}$ \\
\hline & 5 & $28.7 \mathrm{~b}$ & $7.6 \mathrm{a}$ & $406.3 \mathrm{a}$ \\
\hline & 10 & $21.2 \mathrm{c}$ & $5.8 \mathrm{a}$ & $210.8 \mathrm{~b}$ \\
\hline
\end{tabular}

${ }^{\mathrm{z}} \mathrm{l} \mathrm{mg} \cdot \mathrm{L}^{-1}=1 \mathrm{ppm} ; \mathrm{l} \mathrm{cm}=0.3937$ inch; $\mathrm{l} \mathrm{g}=0.0353 \mathrm{oz}$.

${ }^{y}$ For each species, means within a column followed by the same letters are not significantly different according to Fisher's protected least significant difference test $(P \leq 0.05)$. 
Table 4. Two-way analysis of variance with repeated measures of effects of $0,5,8$, and $10 \mathrm{mg} \cdot \mathrm{L}^{-1}(\mathrm{ppm})$ of uniconazole on plant height, flower and fruit number of 'Early Girl' and 'Sun Sugar' tomato during the pretransplanting phase [ 1 to 4 weeks after treatment (WAT)] and the posttransplanting phase (5 to $12 \mathrm{WAT}$ ).

\begin{tabular}{|c|c|c|c|c|c|c|c|}
\hline & \multirow{3}{*}{$\begin{array}{l}\text { Response } \\
\text { variable }\end{array}$} & \multicolumn{3}{|c|}{ 'Early Girl' tomato } & \multicolumn{3}{|c|}{ 'Sun Sugar' tomato } \\
\hline & & $\begin{array}{c}\text { Uniconazole } \\
\text { concn }\end{array}$ & Time & $\begin{array}{c}\text { Uniconazole } \times \\
\text { time }\end{array}$ & $\begin{array}{c}\text { Uniconazole } \\
\text { concn }\end{array}$ & Time & $\begin{array}{c}\text { Uniconazole } \times \\
\text { time }\end{array}$ \\
\hline & & \multicolumn{6}{|c|}{ F ratio } \\
\hline $\begin{array}{l}\text { Pretransplanting } \\
\text { phase }\end{array}$ & $\begin{array}{l}\text { Plant } \\
\text { height }\end{array}$ & $118.79 * * *$ & $371.6^{* * *}$ & 3.38 * * & $77.75^{* * *}$ & $195.10 * * *$ & $6.79 * * *$ \\
\hline \multirow[t]{2}{*}{$\begin{array}{l}\text { Posttransplanting } \\
\text { phase }\end{array}$} & $\begin{array}{l}\text { Plant } \\
\text { height }\end{array}$ & $152.88^{* * *}$ & $5.42 * * *$ & 1.80 ** & $81.23 * * *$ & $62.18 * * *$ & $4.51 * *$ \\
\hline & $\begin{array}{l}\text { Fruit } \\
\text { number }\end{array}$ & $0.67^{\mathrm{Ns}}$ & $3.48 * *$ & $0.52^{\mathrm{Ns}}$ & $3.93^{*}$ & $16.91^{* * *}$ & $2.62^{* *}$ \\
\hline
\end{tabular}

ss $,{ }^{*}, * *{ }^{* * *}$ Nonsignificant or significant at $P \leq 0.05,0.01$, or 0.001 , respectively.

However, plants of 'Millionaire' eggplant and 'Jalapeno' pepper treated with $10 \mathrm{mg} \cdot \mathrm{L}^{-1}$ of uniconazole had significantly lower fruit weight, and lower fruit number and weight, respectively, than the untreated controls or of those treated with $2.5 \mathrm{mg} \cdot \mathrm{L}^{-1}$ of uniconazole (Table 3).

\section{Second experiment}

Effect of uniconazole on plant height and fruit yield of tomato 'Early Girl' and 'Sun Sugar' was studied.

Pretransplanting phase. The two-way ANOVA with repeated measures indicated significant interactions between uniconazole concentration and time on the height of 'Early Girl' and 'Sun Sugar' tomato during the pretransplanting phase (Table 4). Plants of tomato 'Early Girl' and 'Sun Sugar' treated with 5,8 , and $10 \mathrm{mg} \cdot \mathrm{L}^{-1}$ of uniconazole were shorter than untreated plants 1 to 4 WAT. However, there were no significant differences in the height of the tomato plants grown with the different uniconazole concentrations (Fig. IA and B).

Posttransplanting phase. The two-way ANOVA with repeated measures indicated significant interactions between uniconazole concentration and time on the height of 'Early Girl' and 'Sun Sugar' tomato, during the posttransplanting phase, 5 to 12 WAT (Table 4 ). The effect of uniconazole on the height of the two tomato cultivars persisted until the end of the experiment (Fig. $\mathrm{IC}$ and D). Plants of tomato 'Early Girl' and 'Sun Sugar' treated with 5, 8 , and $10 \mathrm{mg} \cdot \mathrm{L}^{-1}$ of uniconazole were still shorter than untreated plants 12 WAT. However, there were no significant

PRE-TRANSPLANTING PHASE
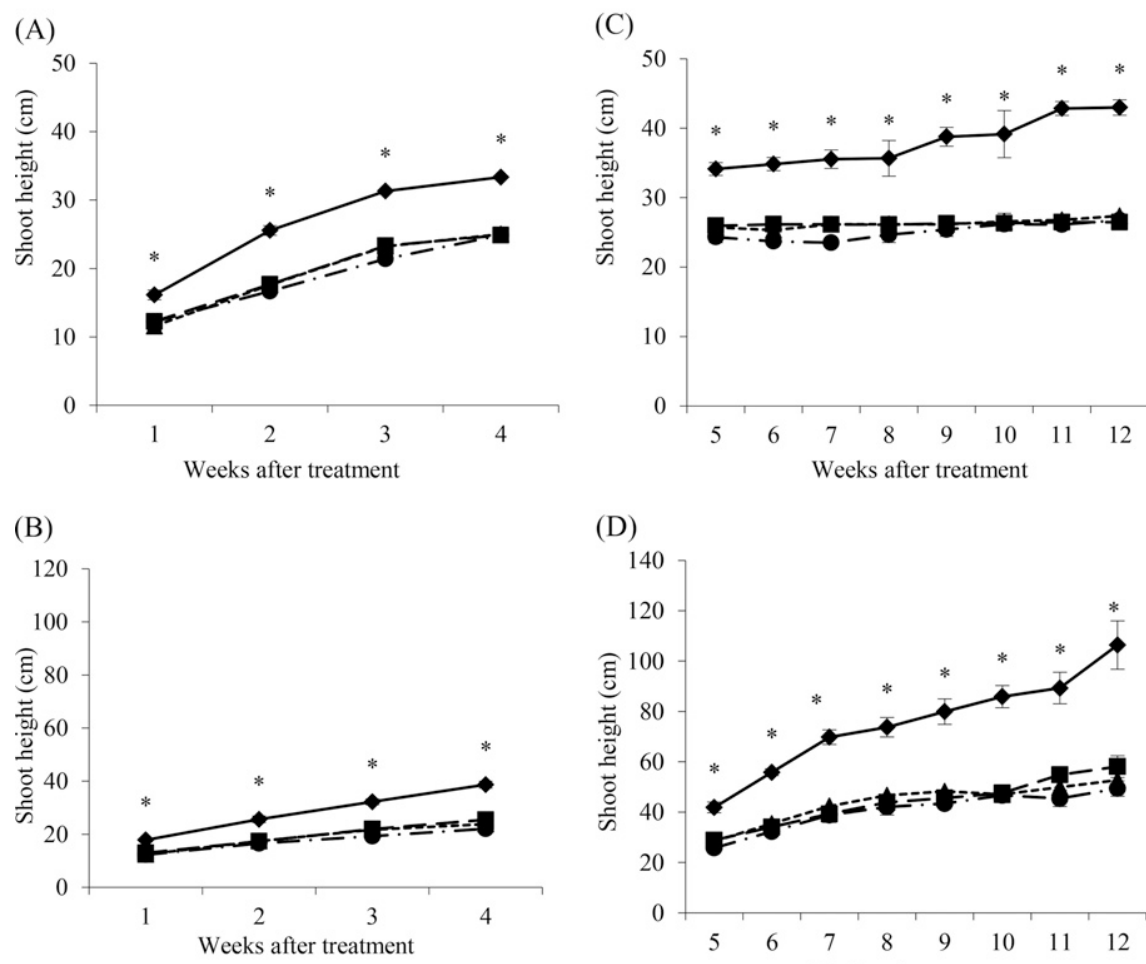

(D)

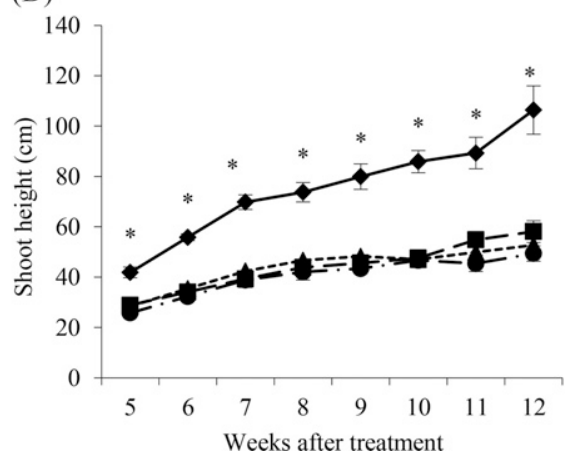

Fig. 1. Effect of uniconazole on the height of (A) 'Early Girl' and (B) 'Sun Sugar' tomato during the pretransplanting phase and (C) 'Early Girl' and (D) 'Sun Sugar' tomato during the posttransplanting phase. Asterisks (*) above the graphs in each date, indicate significant differences among the height of plants treated with $5(-\mathbf{-})$, $8(-\Delta-)$, and $10(-\bullet-) \mathrm{mg} \cdot \mathrm{L}^{-1}$ of uniconazole and the untreated controls $(-\downarrow-)$, at $P \leq \mathbf{0 . 0 5}$, according to Fisher's protected least significant difference test. There were no statistically significant differences in the height of the tomato plants grown with 5,8 , and $10 \mathrm{mg} \cdot \mathrm{L}^{-1}$ of uniconazole; $1 \mathrm{mg} \cdot \mathrm{L}^{-1}=1 \mathrm{ppm} ; 1 \mathrm{~cm}=0.3937 \mathrm{inch}$.

differences in the height of the tomato plants grown with the different uniconazole concentrations (Fig. IC and D).

Application of uniconazole had no effect on the number of flowers and fruit produced by 'Early Girl' tomato. There were no significant differences in the number of flowers or fruit produced by plants of 'Early Girl' tomato treated with uniconazole and the controls from 5 to 12 WAT (Table 4). In contrast, the effects of uniconazole on the number of flowers and fruit of 'Sun Sugar' tomato were significant, although there were interactions with time 
(Table 4). 'Sun Sugar' tomato treated with 5,8 , and $10 \mathrm{mg} \cdot \mathrm{L}^{-1}$ of uniconazole flowered 1 week earlier than untreated controls, and had more flowers, 4 WAT. The mean number of flowers produced by plants treated with $0,5,8$, and $10 \mathrm{mg} \cdot \mathrm{L}^{-1}$ of uniconazole was $( \pm$ SE) $30.4 \pm 3.6,45.4 \pm$ $3.7,50.8 \pm 5.6$, and $64.4 \pm 3.2$ flowers, respectively, 4 WAT. Plants of 'Sun Sugar' tomato treated with 5 and $8 \mathrm{mg} \cdot \mathrm{L}^{-1}$ of uniconazole also had greater number of fruit than the untreated controls and those treated with $10 \mathrm{mg} \cdot \mathrm{L}^{-1}, 6,7$, and $8 \mathrm{WAT}$. The mean number of tomatoes produced by plants treated with $0,5,8$, and $10 \mathrm{mg} \cdot \mathrm{L}^{-1}$ of uniconazole was $( \pm$ SE) $12.8 \pm 2.2,18 \pm 0.8,20 \pm 2$, and $14 \pm 1.4$ fruit, respectively, 8 WAT.

Application of uniconazole had no effect on the total fruit weight of both tomato cultivars. Mean 'Early Girl' tomato total fruit weight ranged from $( \pm$ SE) $517 \pm 80$ to $709 \pm 45 \mathrm{~g}$, and of 'Sun Sugar' from $490 \pm 40$ to $599 \pm 24 \mathrm{~g}, 12 \mathrm{WAT}$.

\section{Discussion}

Our results corroborate the findings of other studies that indicate that plant sensitivity to PGRs varies from one species or cultivar to another (Dunlap et al., 1991; Hammond et al., 2007). Application of uniconazole reduced the height of tomato 'Early Girl' and 'Sun Sugar', 'Jalapeno' pepper and 'Millionaire' eggplant. However, the appropriate concentration of uniconazole to control plant height without affecting other growth parameters varied among plants species. While plant height control might be desirable for size control and shelf life extension, excessive growth suppression can have detrimental effects on plant quality and fruit yield (Dunlap et al., 1991). Compact and attractive looking plants are essential for the nursery grower, but consumers also buy vegetable transplants for their ability to produce fruit. Therefore, fruit yield should not be unfavorably affected by applications of growth retardants during the nurserygrowing phase.

Application of $10 \mathrm{mg} \cdot \mathrm{L}^{-1}$ of uniconazole to plants of 'Jalapeno' pepper and 'Millionaire' eggplant was excessive. It resulted in plants that did not attain commercial size at the end of the experimental period and reduced fruit yield. Treatment with $10 \mathrm{mg} \cdot \mathrm{L}^{-1}$ of uniconazole reduced the number of fruit in pepper plants by $50 \%$ and the total fruit weight in eggplant and pepper plants by $50 \%$ and $32 \%$, respectively. Schnelle (2009) also found that pepper plants were highly responsive to uniconazole. A single spray of uniconazole at $2.5 \mathrm{mg} \cdot \mathrm{L}^{-1}$ reduced the height of 'Hungarian Yellow Wax', 'Big Bertha', and 'Better Belle' pepper plants, and $10 \mathrm{mg} \cdot \mathrm{L}^{-1}$ caused severe stunting. In contrast, Dunlap et al. (1991) reported that uniconazole at $12 \mathrm{mg} \cdot \mathrm{L}^{-1}$ reduced the height of 'Early Jalapeño', 'Hungarian Yellow', and 'Serrano' peppers, but increased their fruit yield.

None of the concentrations of uniconazole decreased the final fruit yield of the two tomato cultivars. Application of $10 \mathrm{mg} \cdot \mathrm{L}^{-1}$ of uniconazole, decreased the height of 'Early Girl' tomato by $25 \%$ during the 5 weeks of the pretransplanting phase (in both, the first and second experiments). In the posttransplanting phase, plants of 'Early Girl' tomato treated with $10 \mathrm{mg} \cdot \mathrm{L}^{-1}$ of uniconazole were still $20 \%$ shorter than the controls 13 WAT (in the first experiment), and $30 \%$ to $40 \%$ shorter than the controls, 12 WAT (in the second experiment). However, there were no significant differences in the fruit weight produced by plants treated or untreated with uniconazole. Application of uniconazole decreased the height of tomato 'Sun Sugar' by $55 \%$, until 12 WAT, but did not affect the final fruit yield, even though 'Sun Sugar' tomatoes treated with all of the uniconazole concentrations had more flowers than the controls, 4 WAT, and more fruit 6 , 7 , and 8 WAT when treated with 5 and $8 \mathrm{mg} \cdot \mathrm{L}^{-1}$ of uniconazole.

Runkle and Blanchard (2012) suggested a starting rate of a single spray of uniconazole at 2.5 to $5 \mathrm{mg} \cdot \mathrm{L}^{-1}$ for 'Lady Bell' pepper and 'Early Girl' tomato, and at 5 to $10 \mathrm{mg} \cdot \mathrm{L}^{-1}$ for 'Little Fingers' eggplant. Application of 2.5 to $5 \mathrm{mg} \cdot \mathrm{L}^{-1}$ of uniconazole seemed appropriate for 'Jalapeno' pepper, and the two tomato cultivars (Early Girl and Sun Sugar) tested in this study until they reached the four-leaf stage. Ten milligrams per liter of uniconazole did not affect tomato fruit yield, but the use of the lowest effective concentration has been recommended to avoid potential adverse effects in the posttransplanting phase (Schnelle and Barrett, 2009). 'Millionaire' eggplant required at least $5 \mathrm{mg} \cdot \mathrm{L}^{-1}$ of uniconazole for height control, but $10 \mathrm{mg} \cdot \mathrm{L}^{-1}$ reduced fruit yield excessively.

Uniconazole has proved to be effective to reduce stem elongation and control the height of containerized herbaceous perennials (Latimer and Scoggins, 2012), bulbs (Damayanthi et al., 2005), woody crops (Cole et al., 2013), vegetables (Dunlap et al., 1991; Hickman et al., 1989), and fruit trees (Le Roux and Barry, 2010). On the basis of our findings, the use of this technique can provide height control and shelf life extension (for the nursery grower), without causing adverse effects on garden performance, reducing fruit yield (for the consumer). However, trials must be conducted to determine appropriate rates for each specific condition (Schnelle and Barrett, 2009). Effects of PGRs on plant growth can be affected by environmental conditions, as well as by the rate (Cochran and Fulcher, 2013), timing (Banko and Landon, 2005; Starman, 1993), and method of application (Pepin and Cole, 2014).

\section{Literature cited}

Al-Rumaih, H. and M.M. Al-Rumaih. 2007. Physiological response of two species of datura to uniconazole salt stress. J. Food Agr. Environ. 5:450-453.

Banko, T.J. and A.L. Landon. 2005. Sumagic (uniconazole) promotes flower bud set on Camellia japonica. J. Environ. Hort. 23:153-157.

Cha-um, S., O. Puthea, and C. Kirdamanee. 2009. An effective in-vitro acclimatization using uniconazole treatments and ex-vitro adaptation of Phalaenopsis orchid. Sci. Hort. 121:468-473.

Cochran, D.R. and A. Fulcher. 2013. Type and rate of plant regulator influence vegetative, floral growth, and quality of Little Lime ${ }^{\mathrm{TM}}$ hydrangea. HortTechnology 23:306-311.

Cole, J.C., R.O. Brown, and M.E. Payton. 2013. Two cultivars of oakleaf hydrangea respond to ancymidol, uniconazole, or pinching. Hort Technology 23:339346.

Damayanthi, N.K., A.P. Ranwala, and W.B. Miller. 2005. Paclobutrazol and uniconazole solutions maintain efficacy after multiple lily bulb dip events. HortTechnology 15:551-553.

Duan, L., C. Guan, J. Li, A.E. Eneji, Z. Li, and Z. Zhai. 2008. Compensative effects of chemical regulation with uniconazole 
on physiological damages caused by water deficiency during the grain filling stage of wheat. J. Agron. Crop Sci. 194:9-14.

Dunlap, J.R., Y. Wang, J.L. Carson, and C.E. Meacham. 1991. Improving the performance of vegetable transplants with a triazole growth retardant. Subtrop. Plant Sci. J. 44:7-10.

Gao, G.Y., B. Bergefurd, and B. Precheur. 2010. Growing tomatoes in the home garden. Ohio State Univ. Fact Sheet HYG-1624-10. 4 May 2015. <http:// ohioline.osu.edu/hyg-fact/1000/pdf/ 1624.pdf>.

Hammond, H.E., R.K. Schoellhorn, S.B. Wilson, and J.G. Norcini. 2007. Differing blanket flower cultivar and ecotype responses to plant growth regulators. Hort Technology 17:552-555.

Hayashi, T., R.D. Heins, A.C. Cameron, and W.H. Carlson. 2001. Etephon influences flowering, height, and branching of several herbaceous perennials. Sci. Hort. 91:305-323.

Hickman, G.W., E.J. Perry, R.J. Mullen, and R. Smith. 1989. Growth regulator controls tomato transplant height. Calif. Agr. 43:19-20.

Keever, G.J. and J.A. McGuire. 1991. Sumagic (uniconazole) enhances flowering of 'Shishi-Gashira' Camellia. J. Environ. Hort. 9:185-187.

Latimer, J.G. and H. Scoggins. 2012. Using plant growth regulators on containerized herbaceous perennials. Virginia Coop. Ext. Publ. 430-103.

Le Roux, S. and G.H. Barry. 2010. Vegetative growth responses of citrus nursery trees to various growth retardants. HortTechnology 20:197-201.

Lurie, S., R. Ronen, and B. Aloni. 1995. Growth-regulator-induce alleviation of chilling injury in green and red bell pepper fruit during storage. HortScience 30:558-559.

National Gardening Association. 2009. The impact of home and community gardening in America. 4 May 2015. <http://www.gardenresearch.com/ files /2009-Impact-of-Gardening-inAmerica-White-Paper.pdf>.

Pepin, R.E. and J.C. Cole. 2014. Paclobutrazol, uniconazole, or flurprimidol applied at various concentrations as a substrate drench or through subirrigation have little effect on bee balm growth. Hort Technology 24:313-317.

Runkle, E. and M. Blanchard. 2012. Sumagic on vegetable transplants. 4 May 2015. <http://www.gpnmag.com/ sumagic-vegetable-transplants $>$.
Schnelle, R. 2009. Sumagic sprays for height control of greenhouse grown tomato and pepper transplants. 4 May 2015. <http://ir4.rutgers.edu/FoodUse/ PerfData/2932.pdf $>$.

Schnelle, R.A. and J.E. Barrett. 2009. Sumagic and tomato transplants. 4 May 2015. <http://www.gpnmag.com/ sumagic-and-tomato-transplants $>$.

Shin, G.W., S.J. Hwang, I. Sivanesan, and R. Jeong. 2009. Height suppression of tomato plug seedlings by an environment friendly seed treatment of plant growth retardants. Afr. J. Biotechnol. 8:41004107.

Starman, W.T. 1993. Ornamental pepper growth and fruiting response to uniconazole depends on application time. HortScience 28:917-919.

Valent, U.S.A. Corporation. 2008. Sumagic plant growth regulator for use on fruiting vegetable transplants. Supplemental label. 4 May 2015. <http://www. valent.com/Data/Labels/2008-SUM$0011 \% 20$ Sumagic $\% 20$ for $\% 20$ use $\% 20$ on $\%$ 20Fruiting\%20Veg\%20Transplants.pdf>.

Wang, Y.T. and L.L. Gregg. 1990. Uniconazole controls growth and yield of greenhouse tomato. Sci. Hort. 43:55-62. 